\title{
Effect of mouse strain as a background for Alzheimer's disease models on the clearance of amyloid- $\beta$
}

\author{
Hisham Qosa and Amal Kaddoumi* \\ Department of Basic Pharmaceutical Sciences, School of Pharmacy, University of Louisiana at Monroe, Monroe, USA
}

\begin{abstract}
Novel animal models of Alzheimer's disease (AD) are relentlessly being developed and existing ones are being fine-tuned; however, these models face multiple challenges associated with the complexity of the disease where most of these models do not reproduce the full phenotypical disease spectrum. Moreover, different $\mathrm{AD}$ models express different phenotypes that could affect their validity to recapitulate disease pathogenesis and/or response to a drug. One of the most important and understudied differences between $\mathrm{AD}$ models is differences in the phenotypic characteristics of the background species. Here, we used the brain clearance index (BCI) method to investigate the effect of strain differences on the clearance of amyloid- $\beta$ (A $\beta$ ) from the brains of four mouse strains. These mouse strains, namely $\mathrm{C} 57 \mathrm{BL} / 6, \mathrm{FVB} / \mathrm{N}, \mathrm{BALB} / \mathrm{c}$ and $\mathrm{SJL} / \mathrm{J}$, are widely used as a background for the development of $\mathrm{AD}$ mouse models. Findings showed that while $\mathrm{A} \beta$ clearance across the blood-brain barrier (BBB) was comparable between the 4 strains, levels of LRP1, an A $\beta$ clearance protein, was significantly lower in SJL/J mice compared to other mouse strains. Furthermore, these mouse strains showed a significantly different response to rifampicin treatment with regard to $A \beta$ clearance and effect on brain level of its clearance-related proteins. Our results provide for the first time an evidence for strain differences that could affect ability of AD mouse models to recapitulate response to a drug, and opens a new research avenue that requires further investigation to successfully develop mouse models that could simulate clinically important phenotypic characteristics of $\mathrm{AD}$.
\end{abstract}

\begin{abstract}
Abbreviations: AD: Alzheimer's disease; $A \beta$ : amyloid- $\beta$; APP: amyloid- $\beta$ precursor protein; BBB: blood-brain barrier; IDE: insulin degrading enzyme; LC/MS/MS: liquid Chromatography/tandem mass spectrometry; LRP1: low density lipoprotein receptor-related protein-1; NEP: neprilysin; P-gp: P-glycoprotein; TCA: trichloroacetic acid
\end{abstract}

\section{Introduction}

Alzheimer's disease (AD) is the most common cause of progressively irreversible dementia among elderly that is characterized by complex neuropathological lesions. Extensive research has identified amyloid- $\beta$ $(\mathrm{A} \beta)$ and tau-related neuropathologies in the brains of AD patients as the main underlying causes of neurodegeneration, cognitive decline and memory loss $[1,2] . A \beta$ peptides are $39-43$ amino acid peptides derived from proteolytic hydrolysis of amyloid- $\beta$ protein precursor (APP) in neurons and other cells $[3,4]$. The level of $A \beta$ in the brain is controlled by its production and clearance; chronic imbalance between these two processes may result in accumulation of $A \beta$ in the brain [5]. In very rare cases of $A D$ (familial $A D$ ), $A \beta$ accumulation is related to its overproduction [4]. However, mounting evidence suggests that $A \beta$ accumulation in the brain of late-onset "sporadic" AD patients and in some cases of familial $\mathrm{AD}$ is related to its impaired clearance from brain [6]. Brain clearance of $A \beta$ takes place by three major pathways, transport across blood-brain barrier (BBB), degradation in the brain tissue, and bulk flow of cerebrospinal fluid (CSF), however, clearance across the $\mathrm{BBB}$ is considered to be the most efficient route for removing $\mathrm{A} \beta$ from the brain [7].

Mouse is a widely used animal model to study AD pathology and to develop therapeutic approaches to fight AD. Over the last decades, several transgenic mouse models were developed to express different pathological alterations of $\mathrm{AD}$ including amyloid pathology, cerebral amyloid angiopathy, tau pathologies, synaptic loss, dystrophic neurites, reactive gliosis, as well as impairments in synaptic plasticity and learning and memory [8]. Such mouse models exhibit above characteristics to varying extents, and many available studies independently showed a significant difference in $\mathrm{AD}$ pathology between different mouse models [9-11]. Although several AD models are made congenic on inbred strains, usually C57BL/6J, to stabilize the genetic background, most of transgenic mouse models used to model AD are from different strains [12]. Therefore, strain variability could make the expression of pathological $\mathrm{AD}$ phenotype, or the relevance of potential pathogenic mechanisms, difficult to ascertain. Moreover, strain variability could explain differences in drug responses observed between different studies.

$A \beta$ is considered an efficient target for the development of therapeutic agents that enhance its clearance and thus slow $\mathrm{AD}$ progression and related pathologies [5]. Many clinically used drugs and herbal medicines have been investigated for their role in decreasing $\mathrm{A} \beta$ accumulation [13-15]. For example, rifampicin, a widely used antibiotic, was able to attenuate the rate of cognitive decline in mild to moderate $\mathrm{AD}$ patients after 3-month course of $300 \mathrm{mg} /$ day dose [14]. Moreover, we previously reported rifampicin potential to enhance $A \beta$ clearance across the BBB by increasing the expression and activity of $\mathrm{A} \beta$ transport proteins namely low density lipoprotein receptor related

Correspondence to: Amal Kaddoumi, Department of Basic Pharmaceutical Sciences, School of Pharmacy, University of Louisiana at Monroe, 1800 Bienville Dr., Monroe, LA 71201, USA, Tel: 318-342-1460, Fax: 318-342-1737, E-mail: kaddoumi@ulm.edu

Key words: amyloid- $\beta$, blood-brain barrier, clearance, rifampicin, mouse strains Received: April 10, 2016; Accepted: April 27, 2016; Published: April 30, 2016 
protein-1 (LRP1) and P-glycoprotein (P-gp) [15].

In this study we investigated differences in $A \beta$ clearance between wild-type mouse strains that have been used as background inbred for the development of transgenic AD mouse models. Moreover, we assessed the clearance of $A \beta$ from the brain of these mouse strains after treatment with rifampicin.

\section{Materials and methods}

\section{Animals}

C57BL/6, FVB/N, BALB/c and SJL/J wild-type male mice were purchased from Harlan Laboratories (Houston, TX). The mice were 7-8 weeks old with an average body weight of $20 \mathrm{~g}$. Mice were kept under standard environmental conditions $\left(22^{\circ} \mathrm{C}, 35 \%\right.$ relative humidity, $12 \mathrm{~h}$ dark/light cycle) with free access to tap water and standard rodent food. After shipping, mice were allowed to adapt to the new environment for one week before initiating the experiments. All animal experiments were approved by the Institutional Animal Care and Use Committee of the University of Louisiana at Monroe and all surgical and treatment procedures were consistent with the IACUC policies and procedures.

\section{Animals' treatment with rifampicin}

Animals of each strain were divided into two treatment groups; control and rifampicin groups. Each group contained at least four animals. Drug administration was started at 8-9 weeks of age and continued for 3 weeks in all experiments. Mice of control groups received intraperitoneal normal saline once daily. Mice of rifampicin groups received intraperitoneal rifampicin at dose of $20 \mathrm{mg} / \mathrm{kg}$ once daily. Treatments were given intraperitoneal to avoid variability associated with oral administration when given with food where the administered dose will be influenced by the amount of food ingested by each mouse, as well as rifampicin stability.

\section{Brain clearance of ${ }^{125} \mathrm{I}-\mathrm{A} \boldsymbol{\beta}_{40}$}

At the end of treatment period, mice were prepared for brain clearance index study (BCI\%) to assess the clearance of ${ }^{125} \mathrm{I}-\mathrm{A} \beta_{40} 24$ $\mathrm{h}$ after the last dose of rifampicin [15]. $A \beta_{40}$ and $A \beta_{42}$ share similar clearance pathway [16,17], however $A \beta_{40}$ was used in the $\mathrm{BCI} \%$ experiments because unlike $A \beta_{42}$ it has lower tendency to aggregate and for practicality reasons as it has much faster clearance rate than $\mathrm{A} \beta_{42}[18,19]$. In-vivo ${ }^{125} \mathrm{IA} \beta_{40}$ clearance was investigated using the BCI method as described previously [7]. In brief, a stainless steel guide cannula was implanted stereotaxically into the right caudate nucleus of mouse brain that was anesthetized with intraperitoneal xylazine and ketamine (20 and $125 \mathrm{mg} / \mathrm{kg}$, respectively; HenrySchein, NY). After 12 $\mathrm{h}$ recovery period, animals were re-anesthetized and tracer fluid $(0.5$ $\mathrm{ml})$ containing ${ }^{125} \mathrm{I}-\mathrm{A} \beta_{40}\left(30 \mathrm{nM}\right.$, PerkinElmer, MA) and ${ }^{14} \mathrm{C}$-inulin (0.02 mCi, American Radiolabeled Chemicals, MO) prepared in extracellular fluid buffer (ECF) was administered. Thirty minutes' post ${ }^{125} \mathrm{I}-\mathrm{A} \beta_{40}$ injection, brain tissues were rapidly collected for ${ }^{125} \mathrm{I}-\mathrm{A} \beta_{40}$ analysis. Calculations of ${ }^{125} \mathrm{I}-\mathrm{A} \beta_{40}$ clearance were performed as described previously [7]. Using the trichloroacetic acid (TCA) precipitation assay, intact (precipitate) and degraded (supernatant) ${ }^{125} \mathrm{I}-\mathrm{A} \beta_{40}$ were determined in brain tissue using a Wallac 1470 Wizard Gamma Counter (PerkinElmer, MA). ${ }^{14} \mathrm{C}$-Inulin in precipitate and supernatant were also determined using a Wallac 1414 WinSpectral Counter (PerkinElmer, MA). The brain clearance index of ${ }^{125} \mathrm{I}-\mathrm{A} \beta_{40}$ from the brain, $\left(\mathrm{BCI}_{\mathrm{Total}}(\%)\right)$, i.e. clearance across the $\mathrm{BBB}$ and brain degradation was calculated according to Equation 1 . Clearance of ${ }^{125} \mathrm{I}-\mathrm{A} \beta_{40}$ across the $\mathrm{BBB}\left(\mathrm{BCI}_{\mathrm{BBB}}(\%)\right)$ and brain degradation $\left(\mathrm{BCI}_{\mathrm{D}}\right.$ $(\%)$ ) were defined by Equations 2 and 3, respectively.

$$
\begin{aligned}
& B C I_{\text {Total }}(\%)=100-\left[\frac{\left(\frac{\text { Amount of intact }{ }^{125} \mathrm{I}-\mathrm{A} \beta_{40} \text { in the brain }}{\text { Amount of }{ }^{14} \mathrm{C}-\text { inulin in the brain }}\right)}{\left(\frac{\text { Amount of intact }{ }^{125} \mathrm{I}-\mathrm{A} \beta_{40} \text { injected into the brain }}{\text { Amount of }{ }^{14} \mathrm{C} \text { - inulin injected }}\right)} \times 100\right] \\
& B C I_{B B B}(\%)=100-\left[\frac{\left(\frac{\text { Amount of total }{ }^{125} \mathrm{I}-\mathrm{A} \beta_{40} \text { in the brain (intact and degraded) }}{\text { Amount of }{ }^{14} \mathrm{C} \text { - inulin in the brain }}\right)}{\left(\frac{\text { Amount of intact }{ }^{125} \mathrm{I}-\mathrm{A} \beta_{40} \text { injected into the brain }}{\text { Amount of }{ }^{14} \mathrm{C} \text { - inulin injected }}\right)} \times 100\right. \\
& B C I_{\text {Degradation }}(\%)=B C I_{\text {Total }}(\%)-B C I_{B B B}(\%)
\end{aligned}
$$

\section{Brain microvessels isolation}

Brain microvessels were isolated as described previously [15]. Briefly, collected brains were homogenized in ice-cold DPBS with Dounce homogenizer. One volume Ficoll (30\%) was added to the brain homogenate to a final concentration of $15 \%$; the mixture was mixed and then centrifuged ( $5000 \mathrm{rpm}$ for $10 \mathrm{~min}, 4^{\circ} \mathrm{C}$ ). The resulting pellets were suspended in ice-cold DPBS containing $1 \%$ bovine serum albumin (BSA) and passed over a glass beads column. Microvessels adhering to the glass beads were collected by gentle agitation in 1\% BSA in DPBS. Isolated microvessels were used for Western blotting studies.

\section{Western blot analysis}

Protein extracts were prepared from brain microvessels or brain tissue using RIPA buffer containing complete mammalian protease inhibitor mixture followed by centrifugation at 14,000 rpm for $1 \mathrm{~h}$ at $4^{\circ} \mathrm{C}$. The supernatant was collected as the protein extract and stored at $-80^{\circ} \mathrm{C}$ to the time of the experiment. Protein samples, $25 \mu \mathrm{g}$, were resolved on $7.5 \%$ SDS-polyacrylamide gels and transferred onto a nitrocellulose membrane. Membranes were blocked with 2\% BSA and incubated overnight with monoclonal antibodies for P-gp (C-219; Covance Research Products, MA), LRP1 (Calbiochem, NJ), insulindegrading enzyme (IDE), neprilysin (NEP), GAPDH or actin (Santa Cruz Biotechnology, TX). For antigen detection, the membranes were washed and incubated with HRP-labeled secondary IgG anti-mouse antibody for P-gp and GAPDH, anti-rabbit antibody for LRP1 and NEP (Santa Cruz Biotechnology) and anti-goat antibody for actin and IDE (Santa Cruz Biotechnology). The bands were visualized using Pierce chemiluminescence detection kit (Thermo Scientific; Rockford, IL). Quantitative analysis of the immunoreactive bands was performed using Li-Core luminescent image analyzer (LI-COR Biotechnology Inc., Lincoln, NE) and band intensity was measured by densitometric analysis. Three independent Western blotting experiments were carried out for each treatment group.

\section{Measurement of rifampicin concentrations in plasma and brain homogenate samples}

Rifampicin levels in plasma and brain homogenate were quantified using LC/MS/MS system. Mice plasma and brain homogenate were mixed with methanol to precipitate proteins in a ratio of $1: 2(\mathrm{v} / \mathrm{v})$. The samples were vortexed for 30 seconds and centrifuged at 14,000 rpm for $10 \mathrm{~min}$ at $4^{\circ} \mathrm{C}$. The clear supernatant was directly injected into the LC/MS/MS system. Chromatographic separation of rifampicin was performed on Kinetex XB-C18 reversed phase column $(100 \times 4.6 \mathrm{~mm}$ i.d., $2.6 \mu \mathrm{m}$; Phenomenex, CA) with an ODS guard column $(4 \mathrm{~mm} \times$ $3 \mathrm{~mm}$; Phenomenex) using Agilent 1100 series LC system (Agilent Technologies, CA) and 3200 QTRAP LC/MS/MS system (Applied 
Biosystems/MDS Sciex, Foster City, CA) at flow rate of $0.5 \mathrm{ml} / \mathrm{min}$. The injection volume was $10 \mu$ l. The mobile phase used was methanol/ ammonium acetate $10 \mathrm{mM}, \mathrm{pH} 6.8$ (70:30, v/v). The analyte was detected using electrospray ionization interface operated in positive mode. Instrument control and data acquisition were carried out by the Analyst 1.4.1 software (Applied Biosystems). The analyte was detected and quantified by MS/MS in multiple-reaction monitoring (MRM) method. The peak signals of transition from the parent ion to its major fragment $m / z$ 823.3 $\rightarrow 791$ was measured.

\section{Statistical analysis}

Unless otherwise indicated, the data were expressed as mean \pm SEM $(n=4)$. The experimental results were statistically analyzed for significant difference using two-tailed Student's t-test for 2 groups, and one-way analysis of variance (ANOVA) for more than two group analysis. Values of $p<0.05$ were considered statistically significant.

\section{Results}

\section{${ }^{125} \mathrm{IA} \beta_{40}$ Brain clearance index and expression of $\mathrm{A} \beta$ clearance proteins in $\mathrm{C57BL} / 6, \mathrm{BALB} / \mathrm{c}, \mathrm{FVB} / \mathrm{N}$ and SJL/J mice}

$\mathrm{A} \beta$ clearance from the brains of selected four mouse strains have been measured using the BCI\% method. BCI\% method is a modified method from the brain efflux index (BEI\%) technique that we have developed previously to calculate total $A \beta$ clearance, i.e. clearance across the $\mathrm{BBB}$ and clearance by parenchymal degradation of $\mathrm{A} \beta$ [7]. Total clearance of ${ }^{125} \mathrm{I}-\mathrm{A} \beta_{40}$ from the brains of the 4 mouse strains was comparable with $\mathrm{BCI}_{\text {Total }}(\%)$ of $57.2 \% \pm 2.7 \%, 60.6 \% \pm 1.9 \%, 59.7 \% \pm$
$2.1 \%$ and $61.3 \pm 1.7 \%$ (Figure $1 \mathrm{~A}$ ) in $\mathrm{C} 57 \mathrm{BL} / 6, \mathrm{BALB} / \mathrm{c}, \mathrm{FVB} / \mathrm{N}$ and $\mathrm{SJL} / \mathrm{J}$, respectively. Similarly, $\mathrm{BCI}_{\mathrm{BBB}}(\%)$ and $\mathrm{BCI}_{\text {Degradation }}(\%)$ were comparable among the strains with $\sim 35 \%$ of $\mathrm{A} \beta$ was estimated to be cleared across the BBB and $\sim 23 \%$ by brain degradation (Figures $1 \mathrm{~B}$ and $1 C)$. On the other hand, western blot analyses of different $A \beta$ clearance proteins in the mice brains showed similar levels of P-gp, NEP and IDE among all mouse strains, but significantly lower levels of LRP1 at the BBB of SJL/J mice. Densitometric analyses of western blot bands showed $\sim 20 \%$ reduction in LRP1 levels in SJL/J mice compared to the other investigated strains ( $p=0.026$, Figure 1C).

Effect of rifampicin treatment on $A \beta$ clearance from the brains of C57BL/6, BALB/c, FVB/N and SJL/J mice

Next, the effect of rifampicin treatment on $A \beta$ clearance was evaluated after three weeks' treatment course of intraperitoneal rifampicin $(20 \mathrm{mg} / \mathrm{kg}$ once daily). $\mathrm{A} \beta$ clearance experiments were performed $24 \mathrm{~h}$ after the last injection of rifampicin or vehicle. After 24 $\mathrm{h}$ from the last injection of rifampicin, plasma and brain homogenate concentrations of rifampicin were negligible (lower than the method limit of detection of $1 \mathrm{ng} / \mathrm{ml}$ ) as determined by LC/MS/MS. This observation is important to exclude any inhibitory effect of rifampicin on $A \beta$ transport proteins and thus $A \beta$ clearance [15]. Thirty minutes post ${ }^{125} \mathrm{I}-\mathrm{A} \beta_{40}$ microinjection, the $\mathrm{BCI}_{\mathrm{Total}} \%$ values in $\mathrm{C} 57 \mathrm{BL} / 6, \mathrm{BALB} / \mathrm{c}$ and $\mathrm{FVB} / \mathrm{N}$ and $\mathrm{SJL} / \mathrm{J}$ mice were $82.4 \% \pm 2.4 \%, 87.7 \% \pm 1.1 \%, 77.9 \% \pm$ $1.8 \%$ and $50.5 \pm 2.5 \%$ respectively (Figure $2 \mathrm{~A}$ ). These results indicate rifampicin increased $\mathrm{A} \beta-\mathrm{BCI}_{\text {Total }}(\%)$ by $18-27 \%$ in $\mathrm{C} 57 \mathrm{BL} / 6, \mathrm{BALB} / \mathrm{c}$ and $\mathrm{FVB} / \mathrm{N}$ mice, while decreased by $\sim 11 \%$ in SJL/J mice (Figure $2 \mathrm{~A}$ ). The increase in total $\mathrm{A} \beta$ clearance in $\mathrm{C} 57 \mathrm{BL} / 6, \mathrm{BALB} / \mathrm{c}$ and $\mathrm{FVB} / \mathrm{N}$

\section{A}

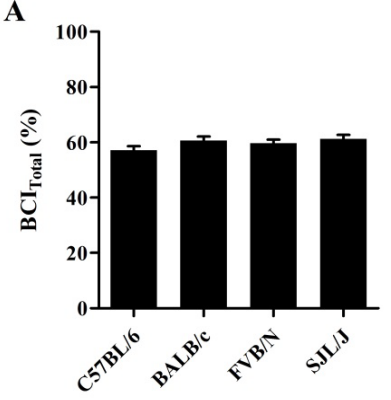

B

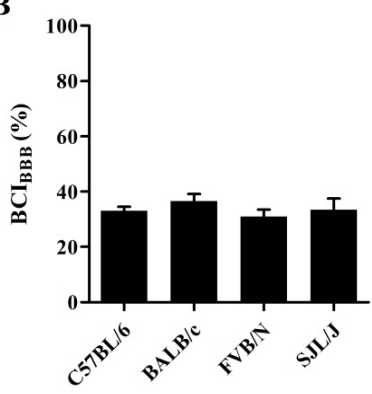

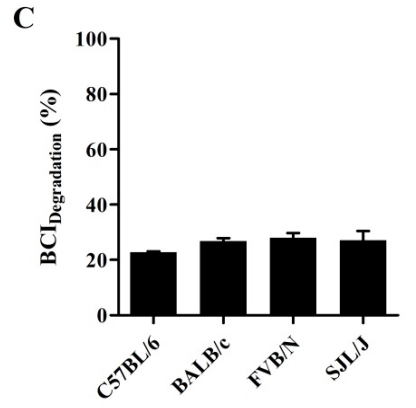

D

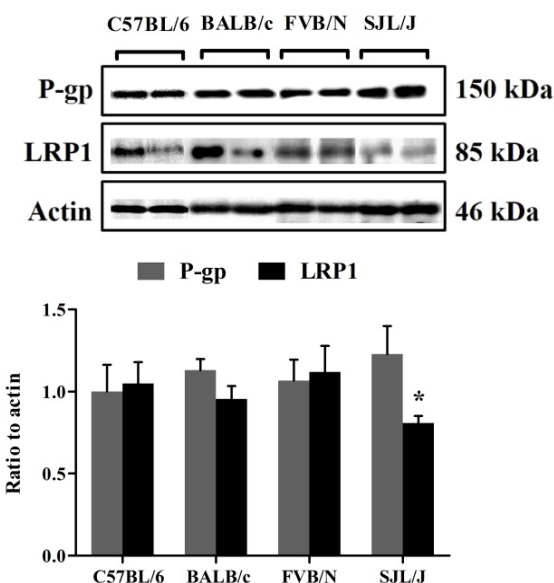

$\mathbf{E}$
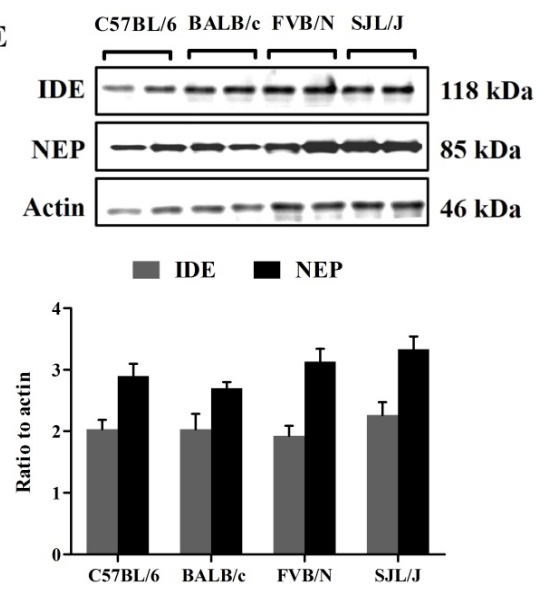

Figure 1. ${ }^{125} \mathrm{I}-\mathbf{A} \beta_{40}$ clearance from the brain of $\mathbf{C 5 7 B L} / 6, \mathbf{B A L B} / \mathbf{c}, \mathbf{F V B} / \mathbf{N}$ and $\mathbf{S J L} / \mathbf{J}$ wild-type mice. Total ${ }^{125} \mathrm{I}-\mathrm{A} \beta_{40}$ brain clearance $\left(\mathrm{BCI} \mathrm{I}_{\mathrm{T} 0 \mathrm{at}}(\%)\right)(\mathrm{A}), \mathrm{BBB}{ }^{125} \mathrm{I}-\mathrm{A} \beta_{40}$ clearance $\left(\mathrm{BCI}_{\mathrm{BBB}}(\%)\right)(\mathbf{B})$ and clearance of ${ }^{125} \mathrm{I}-\mathrm{A} \beta_{40}$ by brain degradation $\left(\mathrm{BCI}_{\mathrm{Degradation}}(\%)\right)(\mathbf{C})$ from the brain of $\mathrm{C} 57 \mathrm{BL} / 6, \mathrm{BALB} / \mathrm{c}, \mathrm{FVB} / \mathrm{N}$ and SJL/J wild-type mice. (D) Representative western blot and densitometry analysis of P-gp, LRP1 and protein loading control (GAPDH) in the brain tissue of C57BL/6, BALB/c, FVB/N and SJL/J wild-type mice. (E) Representative western blot and quantitative fold change for IDE, NEP and protein loading control (GAPDH) in the brain tissue of C57BL/6, BALB/c, FVB/N and SJL/J wild-type mice. The data are expressed as mean \pm SEM of $\mathrm{n}=4$ mice; $* p<0.05$ and $\mathrm{ns}$ is not significant. 
A

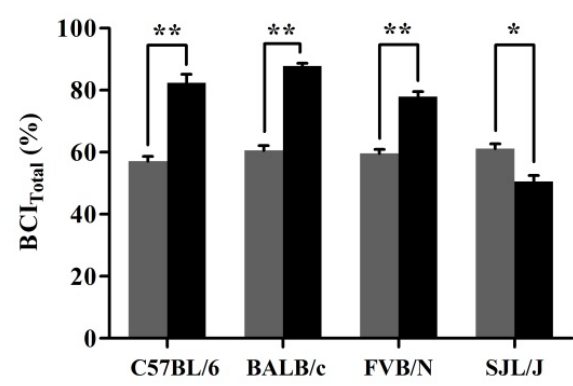

B

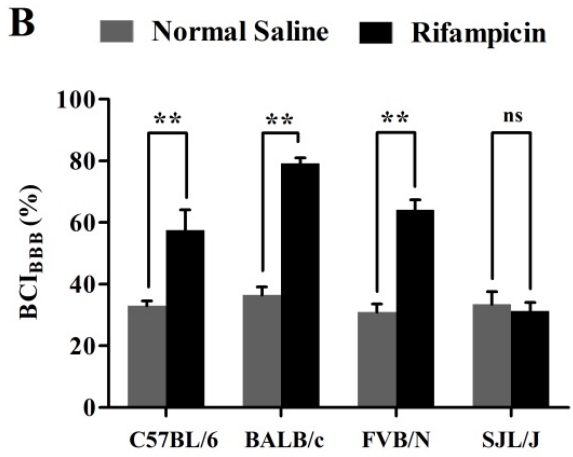

C

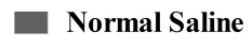

Rifampicin

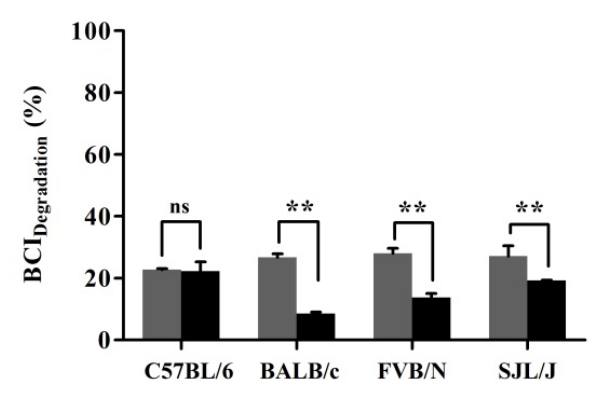

Figure 2. Effect of rifampicin treatment on ${ }^{125} \mathrm{I}-\mathrm{A} \boldsymbol{\beta}_{40}$ clearance from the brain of C57BL/6, BALB/c, FVB/N and SJL/J wild-type mice. Total ${ }^{125} \mathrm{I}-\mathrm{A} \beta_{40}$ brain clearance $\left(\mathrm{BCI}_{\text {Total }}(\%)\right)(\mathrm{A}), \mathrm{BBB}^{125} \mathrm{I}-\mathrm{A} \beta_{40}$ clearance $\left(\mathrm{BCI}_{\mathrm{BBB}}(\%)\right)(\mathbf{B})$ and clearance of ${ }^{125} \mathrm{I}-\mathrm{A} \beta_{40}$ by brain degradation $\left(\mathrm{BCI}_{\text {Degradation }}(\%)\right)(\mathrm{C})$ from the brain of normal saline and rifampicin treated mice. Significant enhancement in total and BBB clearance of ${ }^{125} \mathrm{I}-\mathrm{A} \beta_{40}$ from the brain was observed in all mouse strains after treatment with rifampicin except in SJL/J mice, where a significant reduction in ${ }^{125} \mathrm{I}-\mathrm{A} \beta$ clearance was observed after treatment with rifampicin. On the other hand, ${ }^{125} \mathrm{I}-\mathrm{A} \beta_{40}$ degradation was decreased significantly after treatment with rifampicin in all mouse strains except C57BL/6 mice. Data represent mean \pm SEM for $\mathrm{n}=4$ mice; $* p<0.05, * * p<0.01$ and $\mathrm{ns}$ is not significant.

is specifically owed to the enhanced removal of $A \beta$ across the $B B B$ where rifampicin caused a significant increase in the $\mathrm{BBB}$ clearance of $\mathrm{A} \beta$ by $24 \%, 43 \%$, and $33 \%$ from the brains of $\mathrm{C} 57 \mathrm{BL} / 6, \mathrm{BALB} / \mathrm{c}$ and $\mathrm{FVB} / \mathrm{N}$ mice, respectively (Figure $2 \mathrm{~B}$ ); while $\mathrm{BBB}$ clearance of $\mathrm{A} \beta$ did not change in SJL/J mice after rifampicin treatment $(33.4 \pm 2.9 \%$ and $31.3 \pm 2.2 \%$ in rifampicin and control mice, respectively, Figure $2 \mathrm{~B}$ ). Contrary to $\mathrm{BBB} A \beta$ clearance, brain degradation of $\mathrm{A} \beta$ measured as $\mathrm{BCI}_{\text {Degradation }}(\%)$ was significantly decreased in $\mathrm{BALB} / \mathrm{c}$ by $70 \%, \mathrm{FVB} / \mathrm{N}$ by $50 \%$ and $\mathrm{SJL} / \mathrm{J}$ by $20 \%$ after rifampicin treatment for three weeks
(Figure 2C, $p<0.05$ ). In C57BL/6 mice, however, rifampicin treatment did not alter $\mathrm{A} \beta-\mathrm{BCI}_{\text {Degradation }}(\%)(22.8 \pm 1.9 \%$ and $22.3 \pm 0.8 \%$ in rifampicin and vehicle groups, respectively, Figure $2 \mathrm{C}$ ).

\section{Effect of rifampicin on expression of brain $A \beta$ clearance proteins}

To explain the enhanced clearance of $A \beta$ across the BBB, P-gp and LRP1 protein expressions were examined in mice brains' capillaries. Consistent with the increased clearance of $A \beta$ across the $B B B$, a significant increase in the expression of P-gp and LRP1 was observed with all mice species. Figure 3 shows a significant increase by 26, 20, 22 and 20\% in P-gp expression; and 12, 15, 18 and 22\% in LRP1 expression in the brains' capillaries of $\mathrm{C} 57 \mathrm{BL} / 6, \mathrm{BALB} / \mathrm{c}, \mathrm{FVB} / \mathrm{N}$ and SJL/J mice $(p<0.05)$, respectively (Figure 3$)$.

On the other hand, rifampicin treatment increased the expression of brain A $\beta$-degrading enzymes NEP and IDE only in SJL/J mice, while other mouse strains did not show any change in the levels of these $A \beta$ degrading enzymes (Figure 4). In the brain of SJL/J mice, NEP and IDE expression increased by $20 \pm 2.1 \%$ and $22 \pm 1.5 \%$, respectively $(p<0.05)$, after rifampicin treatment for three weeks. However, this increase in the expression of $A \beta$ degrading enzymes did not enhance brain $\mathrm{A} \beta$ clearance in this mouse strain.

\section{Discussion}

Over the last two decades, several animal models have been developed to dissect the pathogenic mechanisms of $\mathrm{AD}[8,11]$. Most of the transgenic mice have been created in an attempt to generate models of human $\mathrm{AD}$ by overexpressing one or more mutations linked to familial AD. These mice successfully recapitulate many key aspects of $\mathrm{AD}$ [8]. Different background strains are being used to create transgenic mouse models. For example, PDAPP mice have been mostly studied on a highly mixed C57BL6/DBA/Swiss-Webster background. By contrast, Tg2576 mice are typically studied on a hybrid C57BL6/SJL background. Therefore, strain variability could make the expression of pathological Alzheimer's phenotype, or the relevance of potential pathogenic mechanisms, difficult to ascertain [12]. Accordingly, in the current study we examined the effect of strain differences on one of $\mathrm{AD}$ pathological alterations, $\mathrm{A} \beta$ clearance across the $\mathrm{BBB}$, and how this difference may affect a drug response in wild type mice.

To assess the effect of strain differences on $A \beta$ clearance from the brain, we measured $A \beta_{40}$ brain clearance in four mouse strains, $\mathrm{C} 57 \mathrm{BL} / 6, \mathrm{BALB} / \mathrm{c}, \mathrm{FVB} / \mathrm{N}$ and SJL/J mice. These mouse strains were selected because most of transgenic mice that have been developed to model $\mathrm{AD}$ used one of these mouse strains as a background [12]. Our findings showed similar basal $A \beta$ clearance between these mouse strains, with significant contribution of $\mathrm{BBB}$ to the total $\mathrm{A} \beta$ clearance among all strains, which is consistent with our previous findings [7]. However, although all strains showed similar ${ }^{125} \mathrm{I}-\mathrm{A} \beta_{40}$ clearance, analysis of proteins expression showed SJL/J mice to have lower level of LRP1, which suggests species differences in the expression, trafficking, or degradation of this protein at the BBB. Interestingly, available studies showed a positive direct correlation between LRP1 expression and vascular lipid disposition in atherosclerosis, this correlation is consistent with our findings of low LRP1 level in SJL/J mice which are known to be resistant for the development of atherosclerotic lesions $[20,21]$.

Given the difficulty of performing studies in AD patients to validate different therapeutic approaches, the development of animal models has been a high AD research priority. However, although several mouse 


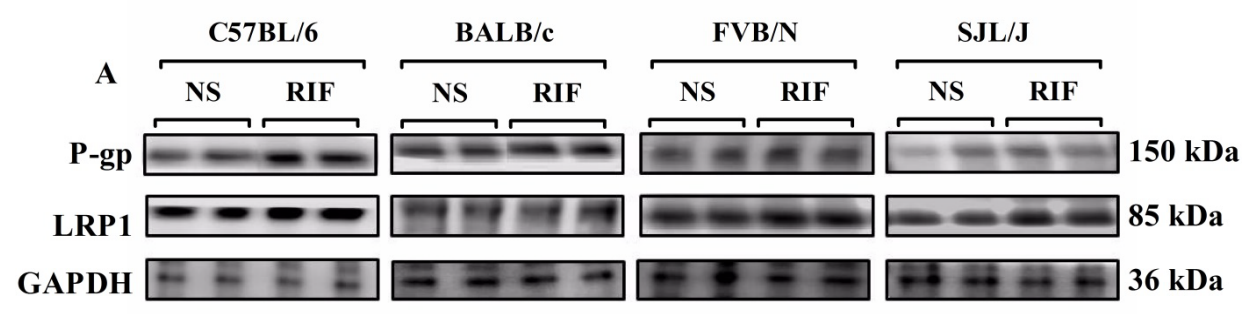

B

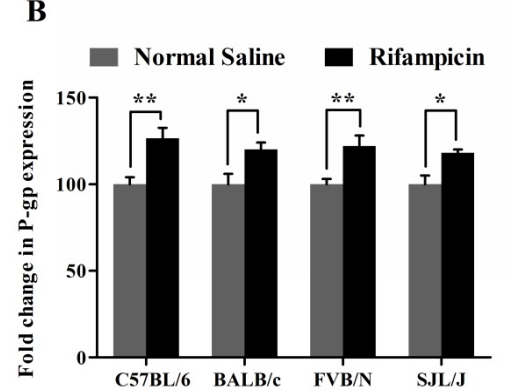

C

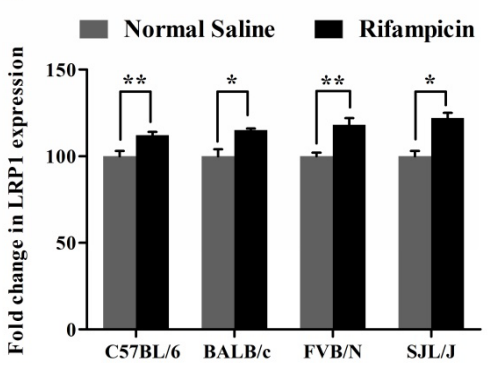

Figure 3. Rifampicin enhances P-gp and LRP1 expression in the brain microvessels of C57BL/6, BALB/c, FVB/N and SJL/J wild-type mice. Western blot analysis showed significantly higher expression level of P-gp and LRP1 in brain microvessels of rifampicin treated mice compared to normal saline treated mice. (A) Representative western blot lanes for P-gp, LRP1 and protein loading control (GAPDH). (B) Quantitative fold increase in P-gp and (C) LRP1 expression in the brain microvessels of C57BL/6, BALB/c, FVB/N and SJL/J wildtype mice after normal saline or rifampicin treatment. The data are expressed as mean $\pm \mathrm{SEM}$ of $\mathrm{n}=3$ independent experiments from $\mathrm{n}=4$ mice; $* p<0.05$ and $* * p<0.01$.
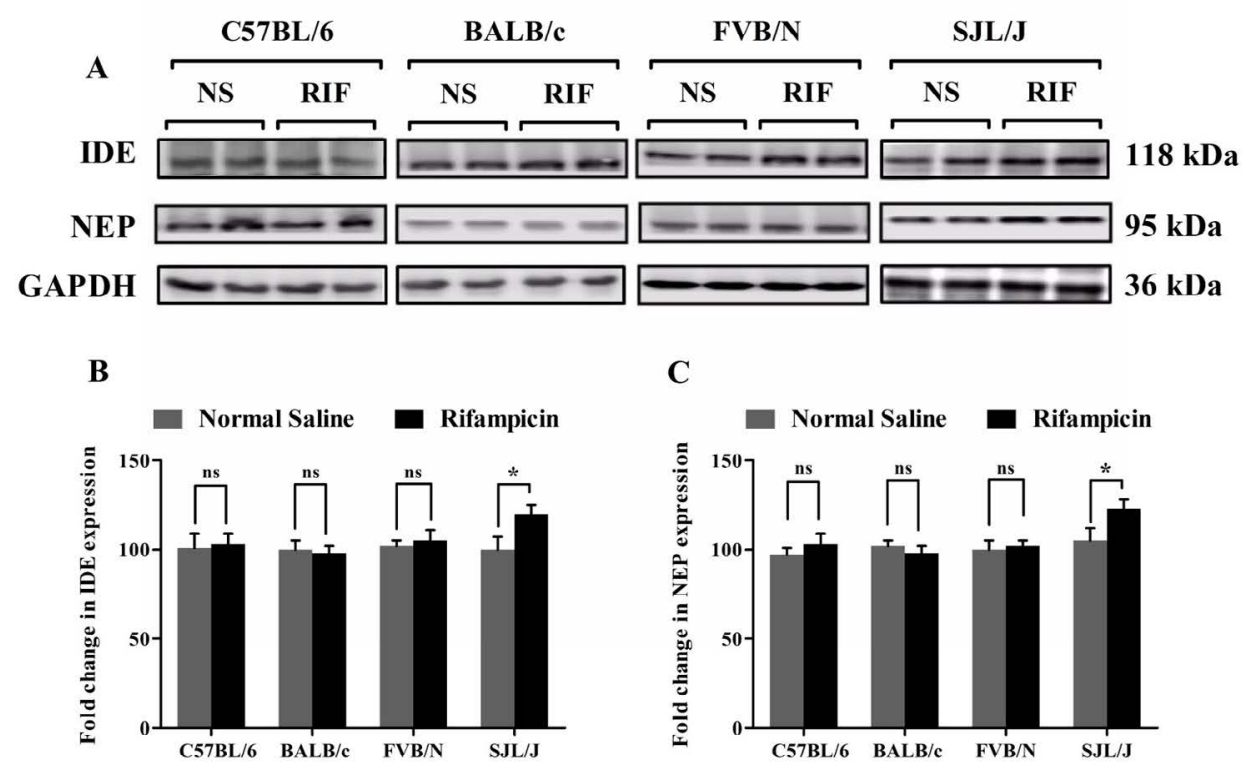

Figure 4. Effect of rifampicin on IDE and NEP expression in the brain tissue of C57BL/6, BALB/c, FVB/N and SJL/J wild-type mice. Western blot analysis showed significantly higher expression of IDE and NEP only in the brain tissue of SJL/J mice after treatment with rifampicin. (A) Representative western blot lanes for IDE, NEP and protein loading control (GAPDH). (B) Quantitative fold change in IDE and (C) NEP expressions in the brain tissue of C57BL/6, BALB/c, FVB/N and SJL/J wild-type mice after normal saline or rifampicin treatment. The data are expressed as mean \pm SEM of $n=3$ independent experiments of $n=4$ mice; ${ }^{*} p<0.05$ and ns is not significant.

models are now being used to test therapeutic approaches, it is yet to be confirmed whether the results from $\mathrm{AD}$ mouse models are reliable predictors of drug efficacy in humans. Therefore, understanding differences in drugs response between different mouse strains would be of great importance to create a reliable mouse model. In this study we evaluated the effect of strain differences on drug response using rifampicin as a model drug for its effect on ${ }^{125} \mathrm{I}-\mathrm{A} \beta_{40}$ clearance from the brain of the four mouse strains. The choice of rifampicin because it is clinically used drug and our previous studies showed potential for this drug to enhance $A \beta$ clearance from the brain through upregulation of $\mathrm{A} \beta$ transport proteins expressed at the BBB [15]. Our findings showed a differential response to rifampicin on ${ }^{125} \mathrm{I}-\mathrm{A} \beta_{40}$ clearance. Following three weeks of rifampicin treatment, $\mathrm{A} \beta$ brain total clearance $\left(\mathrm{BCI}_{\mathrm{Total}}\right)$ increased by $\sim 20 \%$ in the mouse strains C57BL/6, BALB/c, and FVB/N, but significantly reduced in SJL/J mice (Figure 2). This enhanced total brain clearance was correlated with increased clearance across the BBB in 3 of the strains except in SJL/J mice. The increase in $A \beta$ brain clearance across the $\mathrm{BBB}$ in $\mathrm{C} 57 \mathrm{BL} / 6, \mathrm{BALB} / \mathrm{c}$, and $\mathrm{FVB} / \mathrm{N}$ 
strains could be explained, at least in part, by the upregulation of $A \beta$ transport proteins LRP1 and P-gp. Recent findings from our laboratory demonstrated major contribution of LRP1 and P-gp to the clearance of $\mathrm{A} \beta$ across the $\mathrm{BBB}$ of $\mathrm{C} 57 \mathrm{BL} / 6$ that when modulated with selective inhibitors, with or without treatment with rifampicin, significantly reduced the clearance of $A \beta$ [7]. However, while rifampicin increased expression of these proteins at the $\mathrm{BBB}$ of $\mathrm{SJL} / \mathrm{J}$ mice, this increase was not able to enhance $B B B$ or total clearance of $A \beta$, suggesting involvement of alternative or additional protein(s)/pathway(s) that significantly contribute to $A \beta$ brain clearance to compensate for lower levels of LRP1 in SJL/J mice, which could be suppressed by rifampicin treatment. Further investigations are required to confirm and identify these proteins.

Degradation pattern and magnitude were also different. Rifampicin treatment significantly reduced $A \beta$ degradation in $B A L B / c, F V B / N$ and $\mathrm{SJL} / \mathrm{J}$ strains with highest reduction in $\mathrm{BALB} / \mathrm{c}$ strain, but not in $\mathrm{C} 57 \mathrm{BL} / 6$. Yet, this reduced degradation in $\mathrm{BALB} / \mathrm{c}$ and $\mathrm{FVB} / \mathrm{N}$ mice did not alter the total clearance which could be explained, at least in part, by the significant increase in $A \beta$ clearance across the BBB. This result further signifies the important role of the BBB in the clearance of $A \beta$ compared to other clearance mechanisms including degradation.

Collectively, findings from this study suggest strain differences in $A \beta$ clearance, which were further emphasized with rifampicin treatment. SJL/J strain showed lower levels of $A \beta$ transport protein LRP1, and different response in A $\beta$ clearance to rifampicin treatment. Indeed, further studies on the effect of strain type of the background animal that is being used in the development of $\mathrm{AD}$ mouse model are required to achieve the goal of producing mouse models that could recapitulate clinically important phenotypic characteristics of $\mathrm{AD}$.

\section{Acknowledgement}

This work was supported by Institutional Development Award (IDeA) from the National Institute of General Medical Sciences of the National Institutes of Health under grant number P20GM103424, and by National Institute of Neurological Disorders and Stroke under grant number R15NS091934.

\section{Authors' contribution}

All authors contributed to the creation of the manuscript, and read and approved the final version of the manuscript. HQ designed the experiments, performed the studies, conducted data analyses and wrote the manuscript. AK designed the experiments, performed data analyses and edited the manuscript.

\section{References}

1. Scheltens P, Blennow K, Breteler MM, de Strooper B, Frisoni GB, et al. (2016) Alzheimer's disease. Lancet. [Crossref]

2. Hardy J (2006) A hundred years of Alzheimer's disease research. Neuron 52: 3-13. [Crossref]

3. Sun X, Chen WD, Wang YD (2015) $\beta$-Amyloid: the key peptide in the pathogenesis of Alzheimer's disease. Front Pharmacol 6: 221. [Crossref]
4. Hardy J (2009) The amyloid hypothesis for Alzheimer's disease: a critical reappraisal. J Neurochem 110: 1129-1134. [Crossref]

5. Karran E, Mercken M, De Strooper B (2011) The amyloid cascade hypothesis for Alzheimer's disease: an appraisal for the development of therapeutics. Nat Rev Drug Discov 10: 698-712.[Crossref]

6. Sagare AP, Bell RD, Zlokovic BV (2013) Neurovascular defects and faulty amyloid- $\beta$ vascular clearance in Alzheimer's disease. J Alzheimers Dis 33 Suppl 1: S87100. [Crossref]

7. Qosa H, Abuasal BS, Romero IA, Weksler B, Couraud PO, et al. (2014) Differences in amyloid- $\beta$ clearance across mouse and human blood-brain barrier models: kinetic analysis and mechanistic modeling. Neuropharmacology 79: 668-678. [Crossref]

8. LaFerla FM, Green KN (2012) Animal models of Alzheimer disease. Cold Spring Harb Perspect Med 2. [Crossref]

9. Cirrito JR, May PC, O’Dell MA, Taylor JW, Parsadanian M, et al. (2003) In vivo assessment of brain interstitial fluid with microdialysis reveals plaque-associated changes in amyloid-beta metabolism and half-life. J Neurosci 23: 8844-8853. [Crossref]

10. Barten DM, Guss VL, Corsa JA, Loo A, Hansel SB, et al. (2005) Dynamics of \{beta $\}$ amyloid reductions in brain, cerebrospinal fluid, and plasma of \{beta $\}$-amyloid precursor protein transgenic mice treated with a $\{$ gamma\}-secretase inhibitor. $J$ Pharmacol Exp Ther 312: 635-643. [Crossref]

11. Elder GA, Gama Sosa MA, De Gasperi R (2010) Transgenic mouse models of Alzheimer's disease. Mt Sinai J Med 77: 69-81. [Crossref]

12. Duff K, Suleman F (2004) Transgenic mouse models of Alzheimer's disease: how useful have they been for therapeutic development? Brief Funct Genomic Proteomic 3: 47-59. [Crossref]

13. Chen X, Ghribi O, Geiger JD (2010) Caffeine protects against disruptions of the bloodbrain barrier in animal models of Alzheimer's and Parkinson's diseases. J Alzheimers Dis 20 Suppl 1: S127-141. [Crossref]

14. Loeb MB, Molloy DW, Smieja M, Standish T, Goldsmith CH, et al. (2004) A randomized, controlled trial of doxycycline and rifampin for patients with Alzheimer's disease. J Am Geriatr Soc 52: 381-387. [Crossref]

15. Qosa H, Abuznait AH, Hill RA, Kaddoumi A (2012) Enhanced brain amyloid- $\beta$ clearance by rifampicin and caffeine as a possible protective mechanism against Alzheimer's disease. J Alzheimers Dis 31: 151-165. [Crossref]

16. Shibata M, Yamada S, Kumar SR, Calero M, Bading J, et al. (2000) Clearance of Alzheimer's amyloid-ss(1-40) peptide from brain by LDL receptor-related protein-1 at the blood-brain barrier. J Clin Invest 106: 1489-1499. [Crossref]

17. Cirrito JR, Deane R, Fagan AM, Spinner ML, Parsadanian M, et al. (2005) P-glycoprotein deficiency at the blood-brain barrier increases amyloid-beta deposition in an Alzheimer disease mouse model. J Clin Invest 115: 3285-3290. [Crossref]

18. Ito S, Ohtsuki S, Terasaki T (2006) Functional characterization of the brain-to-blood efflux clearance of human amyloid-beta peptide (1-40) across the rat blood-brain barrier. Neurosci Res 56: 246-252. [Crossref]

19. Zlokovic BV, Yamada S, Holtzman D, Ghiso J, Frangione B. (2000) Clearance of amyloid beta-peptide from brain: transport or metabolism? Nature Med 6: 718-719. [Crossref]

20. Costales P, Fuentes-Prior P, Castellano J, Revuelta-Lopez E, Corral-Rodriguez MA, et al. (2015) K Domain CR9 of Low Density Lipoprotein (LDL) Receptor-related Protein (LRP1) Is critical for Aggregated LDL-induced foam cell formation from human vascular smooth muscle cells. J Biol Chem 290: 14852-14865. [Crossref]

21. Nishina PM, Wang J, Toyofuku W, Kuypers FA, Ishida BY, et al. (1993) Atherosclerosis and plasma and liver lipids in nine inbred strains of mice. Lipids 28: 599-605. [Crossref]

Copyright: (C2016 Qosa H. This is an open-access article distributed under the terms of the Creative Commons Attribution License, which permits unrestricted use, distribution, and reproduction in any medium, provided the original author and source are credited. 